\title{
Alfabetização de jovens e adultos qual autoestima?
}

\author{
MARIA LÚCIA FERREIRA DE FIGUEIRÊDO BARBOSA \\ Universidade Federal de Pernambuco, Recife, PE, Brasil
}

RESUMO

Em uma pesquisa sobre alfabetização de jovens e adultos, o tema da autoestima emergiu como categoria de investigação. Ao confrontar o conceito de autoestima com o de faces, este último nos pareceu mais pertinente que aquele, em se tratando de contextos de letramento. Os sujeitos investigados, professores e alunos da alfabetização de jovens e adultos, teceram relação entre autoestima e escrita em entrevistas e histórias de vida, respectivamente. Os docentes enfatizaram a elevação da autoestima como estratégia facilitadora da aprendizagem da escrita. Já os educandos nem sempre manifestaram uma baixa autoestima pela falta da escrita. Os resultados sugerem mais investimento em pesquisas sobre o modo como o éthos dos alfabetizandos regula suas faces e sobre a visão que os alfabetizadores têm acerca da elevação da autoestima e aprendizagem da escrita.

PALAVRAS-CHAVE

alfabetização de jovens e adultos; autoestima; éthos; faces. 


\section{LITERACY OF YOUNG PEOPLE AND ADULTS: WHAT SELF-ESTEEM?}

\section{ABSTRACT}

In a survey of literacy of young people and adults, the topic of self-esteem emerged as an investigation category. When confronting the concept of self-esteem versus the concept of faces, the latter seemed more pertinent than the former, considering literacy contexts. Those investigated, teachers and students of literacy, related self-esteem to writing in both interviews and life stories, respectively. Teachers emphasized the increase of self-esteem as a facilitator of learning strategies for writing. Students, however, did not always manifest low self-esteem for not knowing how to write. The results suggest more investment in research on how the literacy students' éthos regulates their faces and the teachers' view of it.

\section{KEYWORDS}

literacy of young people and adults; self-esteem; éthos; faces

\section{ALFABETIZACIÓN DE JÓVENES Y ADULTOS: ¿CUÁL AUTOESTIMA?}

\section{RESUMEN}

En una pesquisa sobre alfabetización de jóvenes y adultos, el tema de la autoestima surgió como tema de investigación. Cuando hicimos el enfrentamiento del concepto de autoestima con el de faces, este último nos pareció más pertinente en relación al otro, tratándose de contextos de letramiento. Los participantes de la investigación, profesores y alumnos de clases de alfabetización de jóvenes y adultos, hicieron relación entre autoestima y escrita en entrevistas e historias de vida, respectivamente. Los maestros enfatizaron la mejora de la autoestima como estrategia facilitadora de aprendizaje de la lengua escrita. Por otro lado, los estudiantes casualmente manifestaron baja autoestima por la falta de la lengua escrita. Los resultados proponen que se hagan más investigaciones sobre el modo como el éthos de los alumnos en proceso de alfabetización regula sus faces y sobre la perspectiva que los maestros adoptan acerca de la mejora de la autoestima y aprendizaje de la lengua escrita.

PALABRAS CLAVE

alfabetización de jóvenes y adultos; autoestima; éthos; faces. 


\section{INTRODUÇÃO}

O surgimento do conceito de letramento frente à penetração da escrita, no mundo atual, trouxe impactos para alguns domínios de estudos em educação, entre os quais podemos destacar o campo da Educação de Jovens e Adultos (EJA), sobretudo no que se refere à relação desse campo com alfabetização de jovens e adultos.

Com a emergência daquele conceito, tornou-se praticamente inviável conceber uma noção de alfabetização como sendo a mera aquisição de um código e dos educandos como indivíduos sem qualquer bagagem de conhecimento sobre objetos da cultura escrita (Ferreiro, 1985).

Esse fato acarreta mudanças que afetam o modo como os indivíduos não escolarizados e/ou pouco escolarizados sobrevivem em sociedades letradas, ${ }^{1}$ tendo em vista que eles desenvolvem estratégias para lidar com a escrita, ainda que não o façam de maneira convencional. Supomos, no entanto, que o escopo das mudanças, anteriormente mencionadas, restringe-se, sobretudo, a meios acadêmico-científicos, não tendo alcançado, de modo efetivo, outros segmentos sociais, nem mesmo no que se refere a agências de letramento como a escola, que persiste em ver e perceber os educandos da alfabetização de jovens e adultos como alguém que não tem bagagem de conhecimento sobre a escrita.

No que diz respeito à imagem de si dos alfabetizandos, esta sofre influências da primazia atribuída a saberes e experiências dependentes da escrita em nossa sociedade em detrimento de saberes e experiências construídos e compartilhados em práticas orais cotidianas. Não se trata, pois, de uma imagem inerente de si, mas de uma imagem socialmente construída, que resulta de avaliações sociais sobre grupos não alfabetizados (Ratto, 2003).

Em um contexto como o atual, em que novos paradigmas desconstroem a fixidez de conceitos que gravitam em torno de concepções sobre a identidade dos sujeitos contemporâneos (Grigoletto, 2006), seria negligência desconsiderar o modo como tradicionalmente temos nos reportado aos indivíduos não alfabetizados.

Não são raras as ocasiões em que nos referimos à imagem dos indivíduos não alfabetizados com categorias eminentemente subjetivas, como é o caso da propalada baixa autoestima atribuída às pessoas que não leem nem escrevem convencionalmente, por falta de inserção em modos de ler e escrever socialmente reconhecidos.

Como pesquisadora, em EJA percebemos a importância de debater sobre a noção de autoestima que é veiculada no campo da alfabetização de jovens e adultos, a fim de situá-la em relação à mudança de paradigma decorrente da penetração do letramento e seu impacto em práticas sociais, privadas e públicas.

Este é o intento deste estudo: debater sobre a noção de autoestima no campo da alfabetização de jovens e adultos, na perspectiva de buscar possibilidades de repensá-la à luz da noção de face (Brown; Levinson, 1987; Goffman, 1967), que, a nosso ver, exorbita a visão psicológica prevalente na circulação do conceito de autoestima.

1 O termo "sociedades letradas" está sendo usado aqui com referência às sociedades que fazem uso da escrita em diferentes práticas sociais, no domínio privado e público. 
Com vistas a alcançar o objetivo pretendido, valemo-nos do itinerário de algumas incursões na pesquisa sobre a identidade de alfabetizandos jovens e adultos, em virtude de virmos investigando esse tema desde 2003, quando participamos como formadora de alfabetizadores do projeto nacional de alfabetização de jovens e adultos - Brasil Alfabetizado. ${ }^{2}$ Assim, procuramos mostrar como, no itinerário de nossas investigações, emergiu o conceito de autoestima em alfabetização de jovens e adultos.

Procuramos mostrar também como no itinerário aludido anteriormente constituímos um objeto de estudo centrado na perspectiva de revisitar o conceito de autoestima com base em aportes sociointeracionais (Goffman, 1967; Brown; Levinson, 1987). Esse objeto de estudo configurou uma nova busca materializada na pesquisa "Alfabetização de Jovens e Adultos: aonde vai a autoestima?".

Por meio dessa pesquisa, investigamos a autoestima no campo da EJA mediante entrevistas a atores sociais envolvidos diretamente com o processo de alfabetização e letramento dos educandos da EJA, no caso específico, professores e alunos do projeto Lição de Vida. ${ }^{3}$ Os resultados alcançados com a análise das entrevistas revelaram que o conceito de face articula-se com uma visão do éthos interacional dos educandos entrevistados e mostraram-nos que as faces são reguladas por expectativas mais amplas que aquelas reconhecidas no conceito subjetivo de autoestima.

A seguir, retomamos com mais vagar o itinerário das pesquisas que vimos desenvolvendo sobre a construção identitária no campo da alfabetização de jovens e adultos e seus desdobramentos em relação à autoestima dos educandos.

\section{O PONTO DE PARTIDA DO ITINERÁRIO: A IDENTIDADE EM ALFABETIZAÇÃO DE JOVENS E ADULTOS}

Como desdobramento de nossa participação no projeto Brasil Alfabetizado do Recife em 2003, propusemos, nesse mesmo ano, a pesquisa "A identidade sociodiscursiva de alfabetizandos jovens e adultos", com o objetivo de investigar, por meio de entrevistas aos educandos do projeto, a imagem que eles tinham de si. Como um dos braços dessa investigação, buscamos também conhecer, por meio de entrevistas semiestruturadas a sete alfabetizadoras, a quem formávamos para atuar no projeto mencionado, ${ }^{4}$ os processos identitários dessas professoras, conjuntamente

2 Em Recife esse projeto foi denominado "Programa de Mobilização e Alfabetização de Jovens e Adultos: rede de solidariedade para a cidadania", realizado em parceria entre a Prefeitura Municipal do Recife, a Universidade Federal de Pernambuco (UFPE), a Universidade Federal Rural de Pernambuco (UFRPE) e a Universidade de Pernambuco (UPE).

3 Projeto desenvolvido pela Secretaria de Educação, Esporte e Lazer (SEEL) da cidade do Recife, em parceria com o Projeto Brasil Alfabetizado.

4 Os alfabetizadores envolvidos nesse programa eram alunos das diferentes licenciaturas das três universidades parceiras, que recebiam a formação em sua instituição de origem. Entrevistamos apenas alfabetizadoras-alunas da UFPE. 
aos processos identitários de seus educandos. Buscamos saber quais seriam, para as docentes investigadas, as maiores dificuldades por elas enfrentadas no ensino da leitura e da escrita aos alfabetizandos adultos.

Os resultados dessas entrevistas mostraram que, à luz das avaliações das respostas das alfabetizadoras em formação, a "baixa autoestima" dos educandos constituía um dos principais desafios para o aprendizado da leitura e da escrita (Barbosa, 2005a).

Ao confrontarmos os resultados das entrevistas às alfabetizadoras com os resultados das entrevistas a seus alunos, alfabetizandos do Projeto Brasil Alfabetizado do Recife, observamos que a baixa autoestima de que falavam as alfabetizadoras, de modo reiterado, tinha relação com o modo como os alunos se avaliavam em relação à escrita e ao seu processo de aprendizagem.

Porém, na interpretação do discurso das alfabetizadoras, percebemos que o conceito de autoestima era, via de regra, empregado em uma acepção de senso comum e tinha como referência o que elas designavam como "insegurança" dos aprendizes em relação a aprender a ler e escrever.

$\mathrm{Na}$ visão das alfabetizadoras entrevistadas, os educandos apresentariam, naturalmente, uma baixa autoestima que precisaria ser trabalhada. Esse trabalho dependeria de esforço e tempo despendidos no ato de convencê-los sobre sua capacidade para o aprendizado da leitura e da escrita. Essa visão nos foi mostrada por V.M. C., ${ }^{5}$ uma alfabetizadora do projeto, quando, ao ser indagada a respeito do que para ela seria o maior desafio da alfabetização de jovens e adultos, respondeu: "Mobilizar primeiro a turma e convencê-los que ainda há tempo para estudar, que eles têm, sim, capacidade para aprender, tendo que trabalhar a autoestima da classe".

$\mathrm{Na}$ tentativa de compreendermos o conceito em tela, com base no qual as alfabetizadoras justificavam as dificuldades de seus alunos no processo de alfabetização e letramento, procuramos (re)visitá-lo por meio de ensaio em que argumentamos sobre a "necessidade de uma maior compreensão e possível atualização da noção de autoestima em alfabetização de jovens e adultos, tendo em vista o quanto o conceito se encontra, do ponto de vista semântico, carregado de conotação psicológica" (Barbosa, 2008, p. 192).

No referido ensaio, assumimos, de modo explícito, que é "a partir de um quadro de referências interacionais que os alfabetizandos adultos, sujeitos da pesquisa, reclamam uma identidade cuja relação com as práticas de leitura e de escrita lhe assegure respeito e aprovação social, bem como autonomia" (idem, p. 204). Além da assunção desse ponto de vista, defendemos também que uma noção de autoestima

coerente com as atuais demandas da alfabetização de jovens e adultos vai ao encontro das faces dos aprendizes e vislumbra como eles veem a si, como compartilham suas trajetórias de vida através do discurso oral, que passa a fazer parte das práticas cotidianas da sala de aula. (idem, ibidem)

5 A título de preservação da imagem dos entrevistados, o nome será abreviado. 
Em última instância, traduzimos a essência de nossas reflexões na refutação da ideia de que é pertinente elevar a autoestima para satisfazer desejos, cuja referência seja unicamente o indivíduo. Como vínhamos pesquisando no âmbito da construção da identidade de adultos em processo de alfabetização e letramento, tínhamos clareza sobre o fato de que a baixa autoestima, comumente atribuída aos adultos não alfabetizados, não poderia ser compreendida somente na perspectiva subjetiva. $\mathrm{O}$ modo como os indivíduos veem a si seria resultante não apenas de suas autoavaliações, mas também de como eles são vistos e avaliados pelos outros com quem interagem, bem como é resultante de sua situação social, econômica e do contexto político (idem).

As reflexões tecidas sobre autoestima, no campo da alfabetização de jovens e adultos, abriram caminho para um quadro de referências (Brown; Levinson, 1987; Goffman, 1967), com base nas quais vimos construindo um objeto de estudo com o objetivo de rever a noção de autoestima, no campo da alfabetização de jovens e adultos.

Como mostramos, autoestima não foi uma categoria definida a priori em nossa pesquisa sobre a identidade em alfabetização de jovens e adultos, mas, sim, emergiu à medida que buscamos conhecer os desafios da alfabetização de jovens e adultos na visão das alfabetizadoras por nós entrevistadas (Barbosa, 2005a).

Com vistas a uma reflexão mais aprofundada sobre a autoestima no campo da alfabetização de jovens e adultos, buscaremos, doravante, dialogar com resultados da pesquisa "Alfabetização de adultos: aonde vai a autoestima?", ${ }^{6}$ cujo campo de investigação propiciou a coleta de discursos sobre autoestima com atores sociais envolvidos diretamente em alfabetização de jovens e adultos - alfabetizadoras e seus educandos.

\section{PARA COMEÇO DE CONVERSA, AONDE VAI A AUTOESTIMA?}

Ao orientarmos a pesquisa "Alfabetização de adultos: aonde vai a autoestima?", tínhamos a ideia de que seria importante (re)visitar o conceito de "autoestima", no que diz respeito à alfabetização de jovens e adultos, com base na noção de face de Brown e Levinson (1987), por considerarmos que o sentido de "autoestima" caminha para a vala comum de uma esfera subjetiva; enquanto o conceito de "face", por resgatar aspectos sociointeracionais e culturais/interculturais, abriria caminho para a compreensão do éthos dos alfabetizandos jovens e adultos em um cenário permeado por diferentes significados que são atribuídos à leitura e à escrita.

A primeira frente da pesquisa, anteriormente mencionada, voltou-se para uma investigação exploratória sobre o conceito de autoestima, em uma perspectiva mais abrangente, na base de dados do portal SciELO, em seus diversos periódicos

6 Investigação desenvolvida no âmbito do Programa de Iniciação Científica (PIBIC-UFPE, 2009-2010), que contou com a estudante de pedagogia Juanna Amélia Cordeiro Silvestre, na qualidade de orientanda. O estudo foi desenvolvido como subprojeto do projeto A Identidade Sócio-Discursiva de Alfabetizandos Jovens e Adultos, desenvolvido e coordenado por nós no Centro de Educação da UFPE. 
on-line e, em seguida, no portal da Associação Nacional de Pesquisa em Educação (ANPEd), com o objetivo de levantar o uso mais restrito do conceito de autoestima no âmbito da pesquisa em alfabetização de jovens e adultos. Para tanto, foram acessadas as produções do GT18 (Grupo de Trabalho "Educação de Jovens e Adultos").

Os resultados do estudo exploratório sobre o conceito mais abrangente de autoestima mostraram abordagens que o tratam como parte integrante do autoconceito dos indivíduos (Suehiro et al., 2009). Nessas abordagens, a autoestima refere-se ao componente afetivo, responsável pelos afetos e emoções que se associam à autoavaliação.

A investigação sobre o uso mais restrito do conceito de autoestima no contexto da alfabetização de jovens e adultos mostrou indícios de que esse termo é usado, em geral, no âmbito das pesquisas, sem qualquer explicitação de seu significado. Nesse uso, o termo "autoestima" parece ter se cristalizado como algo que pode ser elevado ou diminuído dependendo de os desejos dos indivíduos serem atendidos ou não.

Essa cristalização do conceito, no âmbito da alfabetização de jovens e adultos, está presente, por exemplo, em trabalhos de natureza científica, como alguns presentes no portal da ANPEd (GT18). Como exemplo, destaca-se o excerto a seguir: "As lembranças dos alfabetizados sobre as emoções sentidas por eles ao participarem do processo de alfabetização continuam revelando significados que apontam para a necessidade de elevação da autoestima e de autovalorização" (Souza, 2005, p. 5).

Esse excerto mostra que a autoestima é reconhecida como um fator de ordem subjetiva que influencia a relação dos educandos com a alfabetização. Nessa perspectiva, a autoestima teria o foco apenas no indivíduo, que poderia ser passível de "elevação da autoestima e da autovalorização".

Porém, o impacto do letramento na esfera de mudanças conceituais no campo da alfabetização, em particular da alfabetização de jovens e adultos, aponta para a emergência de um aparato teórico-conceitual que ajude a perceber o caminho aonde vai a autoestima de alfabetizandos jovens e adultos. A visão de uma baixa autoestima desses educandos como uma das principiais dificuldades a serem vencidas com vistas a assegurar o sucesso do processo de alfabetização e letramento suscita a seguinte indagação: Mas... que autoestima?

\section{MAS... QUE AUTOESTIMA?}

Ao lançarmos a indagação "Mas... que autoestima?", temos em mente a ideia de que a noção de autoestima está imbricada a conceitos como imagem pública, face, éthos. Os gregos antigos falavam de uma imagem de si construída com o objetivo de se alcançar êxito em um discurso oratório e a chamavam de éthos (Amossy, 2005). Mais recentemente, Kerbrath-Orecchioni (1994), ao relacionar o éthos às faces positiva e negativa - dos interlocutores (Brown; Levinson, 1987), mostrou que é possível entender como diferentes grupos sociais ou comunidades são suscetíveis a investir mais ou menos em um desses aspectos da face na interação verbal. Os valores de indivíduos, grupos e comunidades influenciam o modo como as pessoas 
se comportam na interação, ou seja, o modo como elas constroem a imagem de si a partir das necessidades relacionadas à face positiva e à face negativa.

De certo modo, podemos afirmar que, ao propor a noção de face, Brown e Levinson (idem) recuperaram e revigoraram o conceito de autoestima. Esses teóricos, ao tratarem da complexidade das conversações face a face, reportam-se à "autoestima e à sua preservação" como um jogo dinâmico que afeta, em grande parte, a organização conversacional da qual interlocutores tomam parte. Porém, o termo "autoestima” é mencionado an passant na apresentação à obra supracitada.

Em vez de se reportarem ao termo "autoestima" como conceito afeto à imagem na interação verbal, Brown e Levinson (idem, p. 41) propuseram a face como o cerne de um jogo interacional.

O conceito de face, que foi enunciado pelos autores mencionados com base na noção de imagem pública de Goffman (1967), corresponde a duas dimensões inter-relacionadas no âmbito das conversações face a face:

(1) Face positiva - compreende a imagem pública para a qual os interlocutores desejam reconhecimento. É, por conseguinte, extensiva ao desejo de aprovação nas interações verbais;

(2) Face negativa - corresponde ao desejo de todo indivíduo de ser livre em suas ações, de não sofrer impedimentos em suas ações verbais, de ser autônomo.

Brown e Levinson (1987) reconhecem que nem sempre as faces serão atendidas no curso das interações verbais, tendo em vista que as conversações face a face são potencialmente conflitantes. Com base em uma visão analítica dos atos ameaçadores das faces, esses autores falam de atos de ameaça à face positiva e à face negativa. Reconhecem os primeiros como contendo riscos ao desejo de reconhecimento, de admiração e de valorização da imagem pública dos indivíduos, por exemplo, avaliações negativas, depreciações, acusação e insultos; e os segundos como contendo restrição ao desejo de autonomia, de liberdade de ação, por exemplo, pedidos, ordens, depreciações que coloquem os indivíduos em situação de perda de face. ${ }^{7}$

Diante dessa relativa instabilidade conversacional, emerge o princípio universal de polidez, com vistas a apoiar os participantes de uma determinada troca interacional no intuito de repararem as ameaças às suas faces e às dos outros. Esse reparo envolve um intrincado e complexo jogo das faces que se manifesta linguisticamente por meio de atos de polidez, denominados por Brown e Levinson (idem) de atos de preservação das faces positiva e negativa. São atos de polidez positiva ações como elogiar ou quaisquer outras que visem reconhecer aspectos positivos da

7 O termo "face", na acepção do inglês cotidiano, está ligado às noções de "embaraço", "humilhação", "perda de face". Assim, "face" é algo que pode ser perdido, mantido, enaltecido e precisa ser cuidado na interação. 
imagem pública dos interlocutores; e atos de polidez negativa, aquelas ações com vistas a assegurar sua autonomia.

Nessa perspectiva, o conceito de autoestima deixa de ser apenas uma dimensão subjetiva das interações verbais e passa a ser visto em sua complexidade, por sua imbricação ao conceito de face, que, por sua vez, tem sido revisado por diferentes estudiosos na busca de atualizá-lo em uma perspectiva cultural. Entre esses estudiosos, Kerbrath-Orecchioni (1994) destaca-se com a perspectiva de abordar as faces com base no princípio interacional das diferentes culturas, comunidades, grupos sociais e/ou indivíduos. A esse perfil interacional ela chama de éthos, que corresponde ao modo peculiar de cada comunidade, grupo social e/ou indivíduo apresentar-se e comportar-se na interação, levando-se em consideração sua suscetibilidade às necessidades das faces positiva e negativa. Vista na perspectiva das faces, a autoestima relaciona-se ao desejo de ser reconhecido, admirado e respeitado (face positiva), bem como o desejo de ser autônomo.

A autoestima passa a ser vista também em uma perspectiva cultural/intercultural como uma questão que se relaciona ao éthos das comunidades, dos grupos sociais e/ou dos indivíduos. Por conseguinte, é razoável supormos que o conceito de autoestima apresenta-se suscetível a mudanças diante dos impactos do letramento, se considerarmos este como sendo

A condição que assume aquele que aprendeu a ler e escrever. Implícito neste conceito está a ideia de que a escrita traz consequências sociais, culturais, políticas, econômicas, cognitivas, linguísticas, quer para o grupo social em que seja introduzida, quer para o indivíduo que aprende a usá-la. (Soares, 2004, p. 17)

Por ser supervalorizada, a escrita reveste-se de valor social para a sociedade em geral, mas, para os não alfabetizados, pode ser vista como um atributo de valor das classes abastadas: "Como ler e escrever não é para a sua classe social, estar na escola é usurpar um lugar que não the pertence" (Armellini et al., 1993, p. 36 apud Barbosa, 2008, p. 7). Sendo assim, é compreensível que adultos não alfabetizados ressintam-se por não saber ler e escrever convencionalmente, o que repercute em sua face positiva enquanto esfera de desejo de reconhecimento e aprovação, e em sua face negativa enquanto esfera de desejo de autonomia.

Para Barbosa (2005b, p. 1)

O fato de vivermos em uma sociedade que supervaloriza a escrita, em detrimento da fala, leva os indivíduos que não se apropriaram das tecnologias da escrita a desenvolverem expectativas tanto em relação à imagem que eles têm de si enquanto pessoas não alfabetizadas como em relação à imagem que lhes é atribuída pelos outros.

Nesse sentido, a visão de que a baixa autoestima é inerente à condição de ser não alfabetizado é um preconceito decorrente de modelos globalizantes de letramento, entendidos aqui como modelos que visam à "filiação de jovens e adultos analfabetos a outro grupo social, isto é, que visa à identificação desses alunos com 
os valores e crenças dos grupos que usam a escrita para fazer sentido da situação nas práticas cotidianas" (Kleiman, 2002, p. 269-271).

Fora e dentro da escola, a identidade dos não alfabetizados é afetada por estereótipos e preconceitos (Galvão; Di Pierro, 2007) que atingem de forma deletéria as faces desses indivíduos. Sendo assim, ao falarmos de noções como autoestima/face, no âmbito da alfabetização de jovens e adultos, precisamos considerar a dimensão interacional desses conceitos, em uma interface com o letramento, enquanto processo de mediação de construção de identidades dos educandos jovens e adultos.

À semelhança de Barbosa (2005b, p. 4), adotamos a ideia de que o fato de a interação social ser um jogo de ajustamento das faces dos interagentes "pressupõe que os processos de construção identitária sejam condicionados, em grande parte, às expectativas das suas faces". É nessa perspectiva que podemos dizer que o conceito de face é muito mais complexo que a acepção usual de autoestima, porquanto, segundo Barbosa (idem), está imbricado no conceito de identidade, o qual é visto por Kleiman (2002, p. 280-281) como

um conjunto de elementos dinâmicos e múltiplos da realidade subjetiva e da realidade social, que são construídos na interação. A construção das identidades é constitutiva da realidade social das práticas discursivas, como a construção de relações sociais entre os falantes e a construção de sistemas de conhecimentos e crenças (ver Fairclough, 1992). As identidades são (re)criadas na interação e por isso podemos dizer que a interação é também instrumento mediador dos processos de identificação dos sujeitos sociais envolvidos numa prática social.

Considerando a emergência do conceito de letramento e seus impactos na forma de ver e de conceber a alfabetização e os alfabetizandos, particularmente no âmbito da alfabetização de jovens e adultos, defendemos aqui a ideia de que o conceito de autoestima não pode prescindir do debate sobre letramento.

Após essa digressão, com o intuito de tecermos relação entre o conceito de autoestima, imagem pública, face e letramento, voltamos, no tópico seguinte, ao diálogo com a pesquisa "Alfabetização de adultos: aonde vai a autoestima?", que teve como sua segunda frente a coleta de dados no âmbito do projeto Lição de Vida da SEEL da cidade do Recife.

\section{AUTOESTIMA/FACE: O CAMPO EMPÍRICO}

A pesquisa anteriormente mencionada pautou-se nos seguintes objetivos: (1) pesquisar o(s) conceito(s) mais correntes de autoestima em alfabetização de adultos, cotejando-os com uma noção intercultural/transcultural de face; (2) analisar atos de linguagem presentes no discurso de alfabetizandos jovens e adultos, tecendo relação entre o que eles dizem sobre a escrita e o modo de expressarem 
sua autoestima/face; (3) conhecer o que os alfabetizadores dizem sobre autoestima em alfabetização de adultos.

O campo de investigação escolhido concorreu para o acesso a perfis diferenciados de alunos e professores que se distribuíam em salas de aula formadas em escolas, sindicatos, associações de bairros, grupos religiosos, entre outros.

Para a escolha dos sujeitos, no que se refere aos professores do projeto mencionado, foram levadas em consideração tanto sua formação como seu tempo de experiência na alfabetização de jovens e adultos. Considerando ainda a assiduidade dos alfabetizadores aos encontros de formação e às salas de aula do projeto, foram selecionados catorze professores para serem submetidos a uma entrevista semiestruturada (Flick, 2009). Porém apenas onze entrevistas puderam ser analisadas, em virtude de falhas técnicas na audiogravação. As entrevistas, que ocorreram no Centro de Treinamento da Prefeitura do Recife em dias de formação dos alfabetizadores, detiveram-se às seguintes questões: 1) Para você, o que é autoestima?; 2) Como você percebe a autoestima de seus alunos durante o processo de alfabetização? Com essas perguntas, buscou-se conhecer o que os alfabetizadores diziam sobre autoestima em alfabetização de adultos.

No que se refere ao objetivo de se conhecer a autoestima na dimensão da história de vida dos alfabetizandos jovens e adultos, alunos do Lição de Vida, foi selecionada uma turma desse projeto, da qual foram escolhidos quatro alfabetizandos que se dispuseram a, por meio de uma entrevista, relatar suas histórias de vida, relacionando-as às suas experiências escolares, em particular às suas experiências com leitura e escrita.

Para coletar dados com os alfabetizandos, utilizou-se a entrevista narrativa, cujo objetivo estaria voltado para a abertura de espaço destinado à apresentação dos sujeitos (idem, ibidem). Nesse sentido, foi lançada a seguinte proposição para a entrevista narrativa: "Gostaria que você me contasse sobre sua vida e os contatos que você teve com a leitura e a escrita. Fale das maiores dificuldades que você enfrentou desde cedo, por não ter aprendido a ler. Pode ser desde quando você era criança até os dias de hoje. Você pode levar o tempo que for preciso, pode entrar em detalhes, pois tudo o que for importante para você nos interessa”.

Tanto as entrevistas com os professores como com alunos foram audiogravadas e transcritas com base no Sistema Mínimo de Notações para transcrições do material do Projeto Norma Urbana Culta da Cidade do Recife (NURC), elaborado por Luiz Antônio Marcuschi (ex-docente e ex-pesquisador da UFPE).

Com base na perspectiva das faces (Brown; Levinson, 1987), foram analisadas as respostas dos sujeitos investigados - alfabetizadoras e alfabetizandos do projeto Lição de Vida. Os resultados dessa imersão nos discursos dos entrevistados são objeto da discussão que passaremos a fazer, aqui, com o intento de compreender qual é o significado da autoestima para alfabetizadores e alfabetizandos da educação de jovens e adultos. 


\section{“PARA VOCÊ, O QUE É AUTOESTIMA?"}

De acordo com a análise das respostas a essa pergunta, percebemos que a acepção usual da autoestima, na visão dos alfabetizadores entrevistados, ${ }^{8}$ é prevalentemente subjetiva, conforme notamos na resposta de M.N.L.L.F.

\section{Exemplo 1}

Autoestima é a valorização pessoal.É uma autovalor... valorização, mas é um... a autoestima é uma coisa que você já tem e que as pessoas... a autoestima de cada pessoa varia de pessoa pra pessoa. Um só por ter o cabelo... é... é... é... achar que o cabelo é cacheadinho... pra ele aquilo é lindo... ele acha aquilo bem... ele tá gostando... e outros com esse aí já achar horrível... e ficar feio: “Meu cabelo é muito feio, num sei o quê...”... outros, por ser um servente, né?... lhe faltam os dentes, mas mesmo assim tem a autoestima... num é? Você olha que ele diz assim "eu quero, eu quero, eu quero...". (M.N.L.L.F., F, 54 anos, pedagoga)

Segundo a resposta ilustrada, a autoestima é inerente ao indivíduo e, por conseguinte, é inteiramente dependente do conceito que se tem de si. Nessa concepção, a autoestima pode ser relacionada a atributos físicos e pessoais valorizados ou não pelas pessoas. Trata-se de uma questão de autoconceito, cuja dimensão é eminentemente afetiva (Burns, 1979 apud Suehiro et al., 2009). Na visão da entrevistada, a autoestima independe de fatores sociais, como ter uma profissão desprestigiada socialmente - "ser um servente" - e de não corresponder aos padrões estéticos da sociedade - "lhe faltam os dentes".

A noção de autoestima que se desvela na resposta de M.N.L.L.F. não resgata o jogo das faces, no sentido de que o indivíduo independe de outrem para aprovação de sua imagem pública. Na perspectiva de Brown e Levinson (1987), as faces resultam de um processo de interação entre falantes e ouvintes. Ambos são afetados por expectativas das faces positiva e negativa, que são de ordem pessoal e social.

Ainda em uma perspectiva subjetiva do conceito de autoestima, verifica-se outra resposta:

\section{Exemplo 2}

Eu acho que autoestima é quando a pessoa fica pra cima, né? Você tá ali embaixo, você... a autoestima da gente fica lá embaixo, a gente se sente tão... eu acho assim: infeliz... autoestima... a pessoa tá infeliz... e, quando a pessoa tem uma coisa boa na vida que fica alegre e feliz, é a autoestima dele que tá lá em cima... a "autaestima" dele tá lá em cima... né isso? Quando você aprende

8 O termo "alfabetizadores" é usado aqui para designar uma categoria de sujeitos da pesquisa, cujo sexo é informado logo após a abreviação dos respectivos nomes - M para masculino e $\mathrm{F}$ para feminino -, bem como são mencionadas a faixa etária e a formação. 
as coisas, tem informações, conhecimento... conhecimento... você fica outra pessoa, então a autoestima vai lá em cima... né isso? (A.M.S., F, 46 anos, magistério)

Esse exemplo é ilustrativo do modo como o conceito de autoestima cristalizou-se, em seu uso corrente, como algo que pode ser elevado ou diminuído, dependendo de condições emocionais dos indivíduos, de suas expectativas pessoais, de seus desejos. Como afirma Barbosa (2008), esse fato tem relação com o uso ostensivo do termo pela mídia em busca de vender produtos da sociedade de consumo, cujo conceito de autoestima distancia-se da noção de face, que, por ser um construto interacional, regulado por padrões culturais, não pode ser visto como simples tática de elevação ou diminuição do ego dos indivíduos.

$\mathrm{Na}$ apreciação dos resultados da pesquisa "Alfabetização de adultos: aonde vai a autoestima?", destacam-se algumas respostas que, ao relacionarem a autoestima a expectativas dos indivíduos, levam em consideração o aprendizado da leitura como um aspecto que contribui para adquirir autoestima, conforme mostram os dois exemplos a seguir.

\section{Exemplo 3}

Autoestima?... Eu acho que é quando a pessoa realiza aquilo que ele pretende conseguir... e, quando ele consegue, eu acho que... que... ele... é... ele adquiriu a autoestima dele... assim... aprender a ler, eu acho que é uma autoestima... ele se acha com uma autoestima... aprender a ler... aqueles que num sabem aprender a ler... que quando ele consegue... isso é um estímulo... tá estimulado... ele tá... autoestímulo... é... ele conseguiu aquilo que aprendeu... eu acho que é isso. (J.F.O., F, 51 anos, magistério)

\section{Exemplo 4}

Olhe, autoestima é você... fazer aquilo que você tem vontade... e que não pôde fazer quando era pequeno... ou quando era jovem... ou quando foi adolescente, né... e agora... eu conseguir chegar a um patamar de ler e escrever... eles... pra mim, a autoestima deles é lá em cima... é isso... ele conseguir alguma coisa que num teve condições de conseguir na juventude ou na infância... né?... por causa que um pai ou uma mãe não levou, não teve condições... existem "n" motivos... né? eu acho que a autoestima deles é essa... é eles chegar... ir hoje... entrou cego... e sai com uma visão, né? (C.M.S., F, 52 anos, pedagoga)

Em ambas as respostas, notam-se indícios da escrita como um objeto cultural desejado. Nesse sentido, aproximam-se da noção de autoestima veiculada pela mídia - os indivíduos são dependentes de algum bem, material ou simbólico, para terem autoestima.

No que diz respeito, em particular, à resposta de C.M.S., percebe-se que o conceito de autoestima apresentado por ela está mais próximo de uma avaliação da face positiva (Brown; Levinson, 1987) do alfabetizando jovem e adulto, à medida 
que menciona uma mudança no modo como o aprendiz entrou no processo de alfabetização: "Eu acho que a autoestima deles é essa... é eles chegar... ir hoje... entrou cego... e sai com uma visão... né?".

Considerando que a face positiva é uma dimensão da interação que reclama o desejo de ser admirado, respeitado e reconhecido pelos outros, sair da condição de não alfabetizado para a de alfabetizado implica mudança no modo como o indivíduo vê a si e como ele é visto pelos outros. É essa a ideía que inferimos com base nas respostas de C.M.S., quando observamos que esta alude à metáfora da cegueira. Essa metáfora configura um preconceito recorrente em relação aos não alfabetizados, que são vistos como pessoas que nada veem; logo, nada sabem, além de configurar um preconceito em relação às pessoas cegas.

Há também outras respostas nas quais é possível observar que o conceito de autoestima está próximo da noção de face positiva.

\section{Exemplos 5}

Olha... autoestima... pra mim... é você... tá bem... é você sentir-se bem... principalmente quando alguém te elogia, te estimula, te ajuda... né? e a própria pessoa em si, ela se sentir assim... é bom quando a pessoa... é... muitas vezes nem sabe o significado disso, mas... ela sente uma autoestima, algo bom que vem de dentro dela e que ajuda ao próximo... a autoestima que você tem... muitas vezes chega a ser tão reluzente, tão boa, que passa pra o próximo e ajuda ele também... então eu acho que autoestima é isso... é você estar bem consigo... você passar essa energia, essa coisa boa, sabe?... positividade... e eu procuro passar isso pros meus alunos, eu posso tá com o problema que eu tiver, mas pra eles eu procuro passar que eu tô sempre com autoestima... isso também tem me ajudado muito nas minhas aulas. (I.V.S.S., F, 33 anos, magistério)

Autoestima?... (risos)... autoestima, assim... é tudo... o que nós professores podemos fazer pra levantar a autoestima do ser humano... enfim: tudo... Como você dar um elogio em sala de aula... a eles... se... vamo dizer... se ele fez uma tarefa... um exemplo... se ele fez uma tarefa... aí você elogiar ele: parabéns... tá excelente... tá ótimo. (E.R.A., F, 49 anos, pedagoga)

As respostas de I.V.S.S. e de E.R.A. destacam a visão interacional da imagem pública, ao mencionarem o elogio como uma estratégia para ajudar os alunos a se perceberem de maneira mais positiva. Nesses casos, a autoestima não é vista apenas como inerente às pessoas, mas como algo que precisa ser construído no processo de interação por meio do jogo da face positiva, o qual pressupõe que a atenção às expectativas de ser admirado, respeitado e reconhecido é uma questão de reciprocidade, como mostra a resposta de I.V.S.S.: "Olha... autoestima... pra mim... é você... tá bem... é você sentir-se bem... principalmente quando alguém te elogia"; e a de E.R.A.: "autoestima, assim...é tudo... o que nós professores podemos fazer pra levantar a autoestima do ser humano... enfim: tudo... Como você dar um elogio em sala de aula". 
$\mathrm{Na}$ perspectiva das faces, o elogio é uma estratégia de preservação da face positiva, que tem como foco a imagem pública do outro, atende ao desejo de ser admirado, reconhecido, imitado. Na resposta de E.R.A., o elogio seria uma estratégia para ajudar na autoconfiança dos alfabetizandos jovens e adultos (foco no outro) e, como consequência, para o aprendizado destes. Já para I.V.S.S., o elogio é visto em relação a sua própria face (foco na professora), mas que a ajudaria a mostrar-se "reluzente" para os alunos e a ajudaria em suas aulas.

\section{“COMO VOCÊ PERCEBE A AUTOESTIMA DE SEUS ALUNOS?”}

A análise das respostas sobre como os alfabetizadores viam a autoestima de seus alunos demonstra, às vezes, certa incoerência com o modo como definiram autoestima ao serem indagados sobre tal definição. Um exemplo desse resultado é a resposta de M.N.L.L.F., cuja concepção de autoestima apresentada, no Exemplo 1, centrou-se no autoconceito dos indivíduos. É possível visualizar essa incoerência ao confrontar o Exemplo 1 com o 6, a seguir.

Exemplo 6

Olha, ela é baixa, né?... apesar de, quando eu penso em outros alunos adultos analfabetos, eu acho que o dos meus são bons... eu... tem um fator muito importante aqui... que eles todos são empregados... aqui ${ }^{9}$ num tem desemprego, num existe ... desemprego zero, né?... Documentos... tem todos os documentos, tem emprego, tem alimentação, tem vale-transporte, tem... a maioria é servente, mas... são empregados, e bem empregados, né?... Num fazem biscate... então isso aí é já uma coisa muito boa perante a situação de outros por aí... as mulheres que apanham de noite e no outro dia vem assistir aula, né? Ninguém é... é embriagado, porque eles, pra trabalhar eles num podem beber... eles devem beber no sábado e no domingo, mas durante a semana eles num bebem. Inclusive tem um grupo que mora no alojamento aqui... da própria empresa... aí num bebe... né... todos vêm limpos, tomado banho, né?... é claro que tem muita coisa que num tem... você viu que eu tive que dar o óculos que ele num tinha... um outro eu... é... tava com dor de dente, né?... porque falta-lhe os dentes... mas o suporte principal eles têm... o sindicato... eles têm o sindicato, ... são sindicalizados... agora faltava eles ter mesmo uma autoestima mesmo... era pra querer mais, querer mais, querer mais... porque quem quer mais... tem. Você num viu Bergue? Bonito, bem-arrumado... com corte de cabelo toda semana... pra num ficar cabeludo, né?... tão sempre organizado... tem onde morar, né? (M.N.L.L.F., F, 54 anos, pedagoga)

9 A entrevistada ministrava aulas no espaço de uma empresa de construção civil, cujos funcionários eram seus alunos no Projeto Lição de Vida. 
O confronto desse exemplo com o Exemplo 1, cuja resposta é também de M.N.L.L.F., mostra que a autoestima passou a assumir uma dimensão de natureza social. No Exemplo 1, diferentemente do Exemplo 6, a autoestima independeria da aprovação da face positiva, no que se refere a atributos físicos, como faltar os dentes, por exemplo. Já no Exemplo 6, a valorização da imagem pública dos educandos dar-se-ia também pela aparência física. Esse fato pode ser notado quando M.N.L.L.F. teceu o seguinte comentário: "Você num viu Bergue? Bonito, bem-arrumado... com corte de cabelo toda semana... pra num ficar cabeludo, né?... tão sempre organizado... tem onde morar, né?".

Quando M.N.L.L.F., ainda no desdobramento da pergunta sobre como a docente via a autoestima dos aprendizes, foi indagada sobre a autoestima de seus alunos em relação ao aprendizado da leitura e da escrita, respondeu o seguinte:

Exemplo 7

Eles... fortalece, né?... fortalece a autoestima... porque se eles tão querendo... quando eu falei em ensinar uma rubrica pra que eles, ao invés de botar o dedo, eles rubricar... eles realmente ficaram assim... fã... o olho brilha, né?... e depois que eu acho que quem criou essa história de rubrica... eu num aprendi em lugar nenhum... aprendi aqui... porque eu queria fazer com que eles pensassem... eu via todo mundo pensar... o que vale é assinatura num sei quê... quem inventou a história da rubrica fui eu mesmo... em sala de aula... porque eu, como diretora de escola... toda vez que chegava uma pessoa pra assinar com o dedo eu dizia..."O senhor num sabe fazer duas letras... a primeira letra do seu nome, não?”; “Ah, sei!"; "Pronto... isso é rubrica!”; “Ah, é, professora?”; “É!”. Aí eles... aprendendo... porque eu já me incomodava de ver pais e mães indo assinar pro filho com o dedo, sempre mexeu comigo. Eu achava aquilo muito... muito dolorido.

O Exemplo 7 mostra que, ao fazer relação mais direta da autoestima dos alunos com o aprendizado da leitura e da escrita, M.N.L.L.F. tece uma aproximação entre autoestima e face em uma dimensão não apenas da face positiva, mas também da face negativa dos educandos. Ao destacar o incômodo sentido diante da necessidade de seus alunos, "indo assinar pro filho com o dedo", ela resgata o aspecto da face negativa, no sentido de que todo indivíduo manifesta o desejo de autonomia. No caso dos alfabetizandos jovens e adultos, a aprendizagem da leitura e da escrita confere-lhes a afirmação de sua autonomia em práticas do discurso escrito. A esse respeito, Barbosa (2005b) mostra o quanto os indivíduos que não sabem ler e escrever sentem-se constrangidos quando precisam fazê-lo nos domínios privado e público. No domínio privado, por exemplo, pedir para alguém que leia uma carta, quando quem pede não sabe ler, constitui uma ameaça à face negativa, porque limita a liberdade de ação à medida que viola a intimidade dos indivíduos.

A aproximação entre o conceito de autoestima e o de face surgiu em outros momentos da entrevista com M.N.L.L.F. sempre que a professora destacava o modo como os alunos se apresentavam no início do curso. Segundo ela: 


\section{Exemplo 8}

Ah! Porque eles, quando senta aqui, querem sentar na mesa bem longe, entendeu? ... pra os outros não achar que eles tão querendo ser alfabetizados, né? num querem assumir que são analfabetos... aí... aí porque tem uns que quando chego aí diz: "Não, professora... eu fiz segunda série". Aí eu disse : "Ah, tudo bem, preencha aqui". Quando preenche... nada.

Nos comentários que a docente faz sobre os alunos, ela descreve o modo como eles se apresentam na interação, no âmbito de um espaço de letramento, no início do curso. Essa descrição revela o éthos dos alfabetizandos jovens e adultos, cuja relação com as faces dá-se na dimensão do constrangimento de "assumir que são analfabetos". Podemos notar esse fato também na fala de outra alfabetizadora, conforme ilustra o Exemplo 9.

\section{Exemplo 9}

Porque eles num têm vivência... da... daquilo da sala de aula... entendeu? Ele num tem aquela vivência... então aquilo pra ele é uma coisa nova... tá descobrindo... então eles têm vergonha... eles se envergonham, né? Se reprime, porque ele faz: "Eu num sei ler e escrever, eu num vou falar nada, porque eu vou falar errado!". Tá entendendo? ele num tem vivência de aula, mas tem uma vivência de vida... maior do que eu... maior do que qualquer pessoa... porque o que eles trazem na bagagem é lindo... eles me ensinam coisas que eu não sabia, entendeu? A vivência dele é de vida... é maior... muuuuito do que a do professor... né? Às vezes eu tô dando uma aula, boto uma palavra, com aquela palavra sai uma história... aí ele começa a falar: "Porque isso...!" ÉÉÉ... bonito...é uma vivência muito bonita, sabe? E isso é que é estímulo. É ele chegar numa sala de aula todo... triste, assim... meio acanhadinho... e sai... eu saí... sai aluno meu que... não acredito... eu digo: "Não, isso num era meu aluno"... entendeu? Pronto... pra mim, autoestima é isso... ele sair dali com alguma coisa... ele rendeu, né? Ele levou pra ele alguma coisa... um conhecimento. Num é que ele fosse leigo na vida... na vida ele tem tudo, agora, conhecer... é conhecer a letra... conhecer o número, né, que diz... dinheiro eles num perdem pra ninguém, entendeu? São vivo demais... agora é... agora não... no dia a dia eles têm uma vivência enorme... entendeu? (C.M.S., F, 52 anos, pedagoga)

A esse modo de se apresentar dos alfabetizandos jovens e adultos subjaz a dimensão cultural/intercultural das faces (Kerbrath-Orecchioni, 1994). A escola é uma instituição de letramento, porquanto há nela diferentes culturas - a da escola/ professor; a dos alunos oriundos de grupos não alfabetizados. Apreende-se, na resposta do Exemplo 9, a relação que a professora faz entre a autoestima de seus alunos e o fato de que eles não têm vivência de modo mais amplo e efetivo com a leitura e a escrita.

Mas o modo de os alunos se apresentarem não resultaria apenas do impacto, de certa forma, gerado pelo confronto com uma instituição do letramento como a escola e, em particular, pelo confronto com alguém alfabetizado - a professora -, mas também por uma espécie de vergonha que afeta a face positiva dos aprendizes entre 
si. O Exemplo 10 mostra como uma alfabetizadora entrevistada destaca a timidez dos alunos entre seus pares.

\section{Exemplo 10}

Porque quando ele chega no primeiro dia... ele fica aquele... morgado... assim... como... como tá um com medo do outro, um sabê mais do que o outro... aí depois que eles vão... eles vão... a autoestima deles acho que vai... subindo (J.F.O., F, 51 anos, magistério)

Essa resposta ilustra mais um exemplo de como os sujeitos se apresentam no início do processo da alfabetização. Porém destaca o "medo" que os alunos teriam de seus pares, sobretudo daqueles que têm mais conhecimento sobre a escrita. A observação que a professora faz nesse sentido é pertinente, se considerarmos o fato de que as faces são ameaçadas por relações de poder desiguais. No caso dos alunos que sabem menos, as faces são ameaçadas porque o tipo de relação que se estabelece em condições de conhecimento desigual gera desigualdade nas relações compartilhadas entre os aprendizes.

$\mathrm{O}$ conceito de autoestima que se depreende na resposta de J.F.O. se aproxima do conceito de face, pois resulta da interação. A docente fala de autoestima como algo que se eleva. Porém, essa elevação não se dá à margem de um processo interacional que demandaria tempo, conforme é possível inferir em um trecho de sua fala: "acho que vai... subindo".

\section{“GOSTARIA QUE VOCÊ ME CONTASSE SOBRE SUA VIDA...”}

Os relatos dos alunos sobre suas histórias de vida, sobretudo no que se refere às suas experiências com leitura e escrita, mostram como os educandos manifestaram suas faces durante os relatos de suas histórias de vida, conforme ilustrações dos exemplos a seguir.

No Exemplo 11, vemos que a falta de estudo é mencionada como um problema que afeta a face positiva do entrevistado.

\section{Exemplo $11^{10}$}

[...] é o seguinte... eu não consegui estudar porque o culpado disso tudinho foi meu pai. [...] Lembro que ele dizia: "Você vai pro colégio, você num vai aprender mais nada não, você é burro mesmo!" Num sei o quê... e num deixava a gente estudar (C.V.F., M, 27 anos, trabalha em restaurante)

Ao atribuir culpa ao pai pelo fato de não haver frequentado a escola, C.V.F. demonstra o cuidado de preservar sua face positiva. Não está em questão aqui se

10 Os alfabetizandos, à semelhança dos alfabetizadores, serão identificados pelas iniciais de seus nomes. As iniciais $\mathrm{M}$ e $\mathrm{F}$ se referem ao sexo dos sujeitos. Há menção à idade e à profissão de cada um deles. 
os fatos por ele relatados são verdadeiros, mas sim qual é o significado do discurso dos sujeitos pesquisados e como esse discurso é revelador de suas faces - positiva e negativa. Em que pese o fato de a resposta, em tela, estar eivada de emoções, não significa que a dimensão da face nela manifesta seja apenas de ordem subjetiva. $\mathrm{O}$ fator principal para que C.V.F. evoque de sua memória o que o pai lhe dizia sobre seu desejo de estudar é a necessidade de não colocar em risco a própria face durante um evento comunicativo que, por sua natureza, acarreta risco às faces dos falantes, como é o caso da entrevista.

Em outro momento de sua fala, C.V.F. ratifica o desejo de apresentar uma face em acordo com uma imagem positiva de si. Vejamos esse fato no exemplo seguinte.

Exemplo 12

[...] "o rapaz é trabalhador, num sabe ler, mas dê uma chance a ele que ele desenrola”. Aí foi que eu consegui desenrolar, porque me deram uma chance.

Ao relatar um episódio em que o gerente de um restaurante em que trabalhava interveio em seu favor, no momento em que C.V.F. se encontrava na iminência de perder o emprego, vê-se que o entrevistado enfatiza um aspecto positivo de sua imagem - "o rapaz é trabalhador"; "ele desenrola”. Percebe-se, assim, uma tentativa de preservar sua face por não saber ler e escrever, tendo em vista que o relato versava sobre a relação de C.V.F. com suas experiências escolares, particularmente com as experiências ligadas à falta de oportunidades na esfera da leitura e da escrita.

Durante os relatos, os educandos ratificam a imagem que as professoras têm deles quando falam da vergonha que sentiam por serem analfabetos.

\section{Exemplo 13}

Nunca andava com... documento, porque eu num queria tirar meu documento, que eu tinha vergonha de botar o dedo, né?... tinha maior vergonha... aí eu disse: "Meu Deus do céu, que que eu faço pra mim tirar meus documento? Que vergonha que eu vou passar na frente do povo... botando meu dedão ali! Eu tenho uma vergonha tão grande". (M.A.A. F, 45 anos, presta serviço doméstico em um centro de candomblé) $)^{11}$

Vê-se que a face dessa entrevistada, à medida que foi relacionada ao fato de ela não saber escrever, mostra-se eminentemente interacional. Isso fica claro quando M.A.A.F. afirma o sentimento de vergonha ao se apresentar diante dos outros como alguém que não escreve. $O$ Exemplo 13 contribui para mostrar que o éthos dos alfabetizandos jovens e adultos, ou seja, o modo como eles se apresentam na interação com pessoas que sabem ler e escrever, é marcado por uma perda da

11 Todas as entrevistas com alfabetizandos foram realizadas com alunos cuja sala de aula foi cedida por um centro de candomblé do Recife. 
face - "Que vergonha que eu vou passar na frente do povo, botando meu dedão ali! Eu tenho uma vergonha tão grande".

O Exemplo 13 reforça nosso argumento em favor da ideia de que a autoestima não é inerente aos indivíduos. A tese de que os alfabetizandos jovens e adultos têm uma baixa autoestima inerente é indefensável, se procurarmos compreender a imagem que os aprendizes têm de si. A forma como esses indivíduos se veem resulta, em grande parte, de processos interacionais, os quais não podem ser compreendidos sem levarmos em consideração a relação das faces dos educandos com os padrões culturais e interculturais que regulam o jogo das faces em uma sociedade que supervaloriza o letramento.

A ilustração de outros exemplos mostra que os alfabetizandos jovens e adultos reconhecem em si outros saberes e competências, além de saberem ler e escrever, os quais são avaliados como sendo de suma importância em suas vidas.

Exemplo 14

E aqui eu sou feliz, em Pernambuco, não sei ler, não sei escrever... "mái” sei pelo "meno" me expressar, né?... Conversar um pouco, brincar, sorrir e trabalhar pra manter a mim e a minha família... isso aí eu sei fazer. (M.J.B., F, 82 anos, aposentada)

Nota-se que o que se revela nessa resposta é uma dimensão da face positiva da entrevistada. Ela se mostra naquilo que atende ao seu desejo de ser respeitada pelos outros, bem como naquilo que atenua a perda da sua face - "não sei ler, não sei escrever... mas sei pelo menos...”. Em sua resposta, M.J.B. reconhece, por um lado, a importância da leitura e da escrita, a qual é legitimada pela sociedade contemporânea, mas, por outro lado, demonstra que ler e escrever não são atributos exclusivos para a vida dos indivíduos, mas que há outros saberes e competências experienciais necessários aos processos de interação social e de sobrevivência, os quais não dependem da escola.

A resposta de M.J.B. é ilustrativa do quanto é necessário (re)visitar o conceito de autoestima no âmbito da alfabetização de jovens e adultos, tendo em vista que a mudança na concepção de alfabetização e de alfabetizandos, em decorrência do impacto do letramento, obriga a repensarmos conceitos que abranjam a dimensão do éthos dos grupos sociais discriminados, como é o exemplo dos indivíduos não alfabetizados.

\section{CONSIDERAÇÕES FINAIS}

Neste artigo, buscamos mostrar como a autoestima, no campo da alfabetização de jovens e adultos, constituiu objeto de estudo na trajetória da pesquisa sobre a identidade sociodiscursiva de alfabetizandos jovens e adultos, desenvolvida por nós. Tal objeto de estudo emergiu no curso das reflexões sobre o discurso das alfabetizadoras entrevistadas no âmbito da investigação mencionada. A partir dos resultados alcançados com as entrevistas, sentimos necessidade de desvelar o conceito de autoestima no campo da alfabetização de jovens e adultos, sobretudo quando 
educadoras desse campo, com o objetivo de justificar dificuldades vivenciadas por elas no ensino de leitura e escrita na alfabetização de jovens e adultos, reportaram uma suposta baixa autoestima dos educandos.

Mostramos ainda que essa percepção nos motivou a tecer relação entre autoestima e letramento e nos levou a revisitar o conceito de autoestima, considerando mudanças no conceito de alfabetização, tendo em vista a emergência do conceito de letramento, bem como o impacto deste para os processos identitários de alfabetizadores da EJA e de seus educandos.

Como vimos, a autoestima, em uma acepção mais ampla, revelou-se como a esfera subjetiva dos indivíduos, algo que pode ser manipulado, elevado, à semelhança do que propõe o marketing publicitário, com o objetivo de vender produtos como os de beleza, por exemplo. Essa acepção subjetiva reverbera também no uso mais restrito da noção de autoestima nos meios acadêmicos científicos que produzem conhecimento sobre a EJA.

Essa reverberação do conceito de autoestima desafiou-nos a rever o conceito com base na noção de face, cuja abordagem é interacional e cuja relação com uma noção cultural/intercultural contribuiria para uma compreensão de aspectos do éthos dos alfabetizandos jovens e adultos, enquanto grupo social que se relaciona com os significados da leitura e da escrita do mundo do letramento.

Percebemos que não poderíamos prescindir da pesquisa sobre o conceito de autoestima junto aos atores sociais envolvidos mais diretamente com o contexto da alfabetização de jovens e adultos - alfabetizadores e alfabetizandos. As entrevistas a esses atores sociais ajudaram-nos a explicitar o conceito de autoestima naquele contexto. No que se refere aos alfabetizadores, observamos que o conceito de autoestima definido por eles é, prevalentemente, subjetivo. A análise de excertos das entrevistas a alguns alfabetizadores demonstrou um conceito de autoestima que independe de fatores sociais. Nessa perspectiva, a autoestima não resgata o jogo das faces, como se os indivíduos fossem independentes do reconhecimento e da aprovação dos outros.

Observamos também, nos dados relativos aos alfabetizadores, que a acepção da autoestima é usada também no sentido de algo passível de elevação, a depender da satisfação de desejos individuais. Nesse sentido, bastaria se criar táticas, como o faz a mídia, para elevar a autoestima por meio da manipulação das emoções e afetividade dos indivíduos. Outros resultados referentes ao conceito de autoestima dos alfabetizadores tecem relação mais direta com as expectativas dos alfabetizandos jovens e adultos no que se refere ao aprendizado da leitura e da escrita, o qual teria uma influência sobre a autoestima dos aprendizes.

Mostramos ainda que alguns alfabetizadores teceram aproximação entre $o$ conceito de autoestima e a noção de face ao mencionar o elogio como uma estratégia que contribui para melhorar o aprendizado dos educandos. O elogio seria uma estratégia recíproca do jogo das faces - de ouvintes e falantes - no sentido de que resultaria de um processo de reciprocidade na interação entre os docentes e os alunos.

Ao cruzarmos esses dados com aqueles que resultaram da pergunta sobre como os alfabetizadores veem a autoestima de seus alunos, percebemos que há contradição na concepção de autoestima apresentada, de início, pelos alfabetizadores. Ao falar sobre a autoestima dos educandos motivados pela pergunta sobre como eles veriam essa 
autoestima, os entrevistados tenderam a tecer uma aproximação daquele conceito com as faces dos aprendizes - positiva e negativa -, bem como levaram em consideração a influência de fatores de ordem social, como trabalho e condições de vida.

Esse cruzamento mostrou inclusive que os alfabetizadores descreveram o modo como os alunos se comportariam - tímidos e envergonhados - ao chegar à escola, o que configura o éthos de um grupo social diante do mundo do letramento.

Na perspectiva da história de vida dos alfabetizandos jovens e adultos, percebemos que as faces dos entrevistados revelaram-se na relação com suas experiências de vida, cujas memórias evocaram razões pelas quais não conseguiram aprender a ler e escrever. As faces dos entrevistados mostraram-se afetadas pela "vergonha" de não saber ler e escrever, o que está de acordo com avaliações dos alfabetizadores sobre o modo como os aprendizes apresentam-se no início do curso de alfabetização.

Porém, os resultados mostram também que não há uma unanimidade no modo como os alfabetizandos revelam suas faces ao relatarem as dificuldades que lhes impediram de ser alfabetizados. Esses resultados demonstram o quão importante é considerar os significados da leitura e da escrita para a vida dos jovens e adultos. Enquanto para alguns saber ler e escrever pode ser uma condição para atender expectativas da face positiva, para outros há outros saberes e competências, não escolarizados, que os ajudam a relacionar-se em domínios privados e públicos, bem como a sobreviver às dificuldades da vida.

Consideramos, assim, que o nosso estudo contribui para colocar em xeque a visão de que os alfabetizandos jovens e adultos têm uma baixa autoestima que é inerente ao fato de eles não saberem ler e escrever convencionalmente. $\mathrm{O}$ conceito de faces que se articula com uma visão do éthos interacional dos educandos entrevistados nos mostra que as faces são reguladas por expectativas mais amplas que aquelas que são atribuídas à autoestima em uma acepção corrente.

\section{REFERÊNCIAS}

Amossy, R. (Org.). Imagens de si: a construção do éthos. São Paulo: Contexto, 2005.

Armellini, N. J.; Otero, E. S.; Algayer, R. L.; Baquero, R. V. A. (Coords.). Alfabetização de adultos: recuperando a totalidade para reconstruir a especificidade. Porto Alegre: UFRGS, 1993.

BARbosa, M. L. F. F. A construção da identidade de alfabetizadoras em formação. In: Leal, T. F.; Albuquerque, E. B. C. Desafios da educaşão de jovens e adultos: construindo práticas de alfabetização. Belo Horizonte: Autêntica, 2005a. p. 49-69.

. Leitura e escrita na alfabetização de jovens e adultos: uma questão de autoimagem e identidade. In: Reunião Anual da Associação Nacional de Pós-Graduação e Pesquisa em Educação, 28., 2005, Caxambu. Anais... Caxambu, 2005b. Disponível em: $<\mathrm{http} /$ wwww.anped.otg./reuniões/28/textos/gt18/gt180101.rtf $>$. Acesso em: 30 jul. 2010.

O éthos na alfabetização de adultos: aonde vai a autoestima? Linhas Críticas, Brasília: Faculdade de Educação da Universidade de Brasília, v. 14, n. 27, p. 191-208, jul./dez. 2008. 
Brown, P.; Levinson, S. Politeness: some universals in language usage. Cambridge: University Press, 1987.

Ferreiro, E. Reflexões sobre alfabetização. São Paulo: Cortez, 1985.

Flick, U. Introdução à pesquisa qualitativa. São Paulo: Artmed; Bookman, 2009.

Galvão, A.M. O.; Di Pierro, M. C. Preconceito sobre o analfabeto. São Paulo: Cortez, 2007.

Goffman, E. Interaction ritual: essays on face to face behavior. New York: Basic Books, 1967.

Grigoletto, M. Leituras sobre a identidade: contigência, negatividade e invenção. In: Magalhães, I.; Coracini, M. J.; Grigoleto, M. (Orgs.). Práticas identitárias: língua e discurso. São Carlos: Claraluz, 2006. p. 15-26.

Kerbrath-Orecchoni, C. Les interactions verbales. Tome III. Paris: Armand Colin, 1994.

Kleiman, A. A construção de identidades em sala de aula: um enfoque interacional. In: Signorini, I. (Org.). Linguagem e identidade. São Paulo: Mercado de Letras, 2002.

Ratto, I. Ação política: fator de constituição do letramento do analfabeto adulto. In: Kleiman, A. (Org.). Os significados do letramento. São Paulo: Mercado de Letras, 2003.

Recife. Programa Lição de Vida: quem aprende a ler e escrever muda de vida. Recife: Prefeitura da Cidade do Recife; Secretaria da Educação, Esporte e Lazer, 2009.

SoAres, M. Letramento: um tema em três gêneros. Belo Horizonte: Autêntica, 2004.

Souza, M. D. A. S. Construindo significados: a alfabetização de jovens e adultos para os trabalhadores. In: Reunião Anual da Associação Nacional de Pós-Graduação e Pesquisa em Educação, 28., 2005, Caxambu. Anais... Caxambu, 2005. Disponível em: <http://www.anped.org.br/reunioes/28/inicio.htm>. Acesso em: 18 maio 2010.

Suehiro, A. C. B.; Rueda, F. J. M.; Oliveira, E. Z.; Pacanaro, S. V. Avaliação do autoconceito no contexto escolar: análise das publicações em periódicos brasileiros. Psicologia Ciência e Profissão, Brasília: Conselho Federal de Psicologia, v. 29, n. 1, p. 18 -29, 2009.

\section{SOBRE A AUTORA}

Maria Lúcia Ferreira de Figueirêdo Barbosa é doutora em letras pela Universidade Federal de Pernambuco (UFPE). Professora adjunta da mesma instituição.

E-mail: luciafyg@yahoo.com.br 